\title{
Comparative Antibacterial Efficacy of Vitellaria paradoxa (Shea Butter Tree) Extracts Against Some Clinical Bacterial Isolates
}

\author{
Kamoldeen Abiodun AJIJOLAKEWU*, Fola JoseAWARUN \\ University ofIlorin, Faculty ofLife Sciences, Department of Microbiology, PMB 1515 Ilorin, Nigeria; ajijolakeuruak@unilorin.edu.ng (*correspondingauthor)
}

\begin{abstract}
The antibacterial activities of the ethanolic extracts of seed, leaf and stem bark of Vitellaria paradoxa were investigated. The extracts were tested against three clinical bacterial pathogens, Staphylococcus aureus, Escherichia coli and Klebsiella pneumoniae using the agar diffusion and the broth dilution techniques. Ethanolic extracts of the plant parts showed activity against all the bacterial pathogens tested. At the highest extract concentration $(200 \mathrm{mg} / \mathrm{ml})$, the leaf extract exhibited the highest antimicrobial activity, while no activity was detected at the lowest concentration $(3.13 \mathrm{mg} / \mathrm{ml})$ against the tested isolates. Escherichia coli and Staphylococcus aureus were more susceptible to all extracts of $V$. paradoxa, while Klebsiella pneumoniae showed the least sensitivity. The efficacy of ethanolic extracts of Vitellaria paradoxa was compared to a commercial antibiotic streptomycin. There were differences in the minimum inhibitory concentration (MIC) of all the Vitellaria paradoxa ethanolic extracts with respect to the type of organism. All extracts exhibited bacteriostatic effects against the tested organisms at the experimented concentrations. Qualitative phytochemical screening of the extracts revealed the presence of saponins, tannins and alkaloids as the active principles of Vitellaria paradoxa's antimicrobial activity. $V$.paradoxa could be used as a potential source of antibiotic substance for a drug development.
\end{abstract}

Keywords: agar diffusion, antimicrobial, bacterial pathogens, Escherichia coli, MIC, Staphylococcus aureus

\section{Introduction}

Traditional medicines have been effectively used for thousands of years. The contribution of herbal products to modern medicine is well documented. It is reported that life in most parts of Africa is connected with herbal medicine, while $65 \%-80 \%$ of world's population rely on traditional medicine for their health care needs (Philips et al., 2009; Calixto, 2000; Adamu et al., 2013). In Nigeria, thousands of plant species are known to have medicinal values and the use of different parts of these plants to cure specific ailments has been practiced since ancient times (Rios and Recios, 2005). The medicinal values of plants lie in their phytochemical composition, which produce definite physiological actions on the human body (Mann et al., 1997).

V. paradoxa (formerly Butryspermum paradoxum) or Shea butter, is a popular tree with several applications in folkloric medicine. The tree grows naturally in the wild of the dry savannah belt of West Africa and stretches in abundance onto the foothills of the Ethiopian mountains (Adamu et al., 2013).

In traditional medicine, Shea butter has been employed in the treatment of several ailments. It encourages wound healing and soothes skin irritation. Shea-butter is also used to treat inflammation, rashes in children, dermatitis, chapping and ulcers, as well as rub for rheumatism (Hong et al., 1996). Its leaf decoctions are used for stomach ache, headache and as an eye lotion. Roots and root bark are grounded to paste and taken orally to cure jaundice, or they are boiled and pounded to treat chronic sores. They are also used for the treatment of gastric problems as well as diarrhea and dysentery. Bark decoction is used to facilitate childbirth and to encourage lactation after delivery, or as a footbath neutralizes venom of the spitting cobra (Hall et al., 1996). Cosmetics, especially those that prevent skin drying and good looking lipsticks use Shea-butter. As a result, cosmetic industries market uses these ingredients in soaps, shampoo and skin cream preparations (Hall et al., 1996).

$V$. paradoxa has been studied as a potent medicinal plant (Prescott et al., 2002), against bacterial infections (El-Mahmoud et al., 2008) and fungal infections (Ahmed and Sani, 2013). The ethanolic extraction of the active principle of this medicinal plant has been shown to be more efficacious than when water or acetone (El-Mahmoud et al., 2008) and hot or cold water (Ahmed and Sani, 2013) are used as extractants. The reason for the higher antibacterial activity of the ethanolic extract has been suggested to be due to differences in the polarity of the solvents and the modulatory effect of enzyme such as phenolases and hydrolases released when plant materials are grounded in water (El-Mahmoud et al., 2008). Odebiyi and Sofowora (1978) also showed that potency of a plant extract depends on both the concentration used and the method of extraction.

In line with the need to search for more effective and safe antibacterial drugs and to justify the traditional use of herbal preparations in the treatment of infectious diseases, this work was designed to investigate and compare the antibacterial efficacy of the Vitellaria paradoxa leaf, seed and stem bark against some clinically important isolates and to determine the phytochemical constituents present in those plant extracts. 


\section{Materials and Methods}

\section{Test organisms}

The bacterial species used in this study, Staphylococcus aureus, Escherichia coli and Klebsiella pneumoniae, were obtained from the Department of Microbiology, University of Ilorin Teaching Hospital (UITH), Ilorin, Kwara state. Purity of the cultures was checked at regular intervals as described by Acheampong et al. (1988).

\section{Plant collection and identification}

Samples of the bark, seed and leaf of Vitellaria paradoxa were collected from the trees within University of Ilorin, Ilorin, Nigeria. The plant samples were identified macroscopically as described by Dalziel (1968) and confirmed at the herbarium unit of the Department of Plant Biology, University of Ilorin. The fresh samples were sundried for a week, grounded into a fine powder and kept in plastic containers until further use at room temperature $\left(28 \pm 1^{\circ} \mathrm{C}\right)$.

\section{Preparation of ethanolic extracts}

One hundred grams $(100 \mathrm{~g})$ of each of the plant parts (seed, leaf and stem bark) were soaked into $100 \mathrm{ml}$ of the solvent $(95 \%$ ethanol) in different air-tight sterile jars respectively at room temperature and kept on a shaker (90 $\mathrm{rpm}$ ) with uniform shaking for 24 hours. The solvents containing the extracts were decanted filtered with a muslin cloth and then with Whatman no. 1 filter paper respectively. Further extraction of the grounded samples was done with same volume of $95 \%$ ethanol, decanted and filtered two more times. The filtrates from each round of extraction were combined and were evaporated to dryness in small, open mouth jars and then packed in separate clean dry bottles and stored at room temperature until required.

\section{Sterility of extracts}

Each of the extracts was tested for growth of contaminants. This was done by making serial dilution of $1 \mathrm{~g}$ of each extract up to $10^{-1}$. Twenty microliters $(20 \mu \mathrm{l})$ of the diluents were aseptically inoculated on Nutrient Agar plates and incubated at $37^{\circ} \mathrm{C}$ for 24 hours. The plates were observed for growth. Absence of microbial growth in the extract indicated their sterility. Sterile extracts were used to test for antimicrobial efficacy.

\section{Standardization of inoculums}

Standardized inoculums of each tested organism was obtained by making their respective suspension up to 0.5 McFarland standard as observed in the spectrophotometer and as described by Barry et al. (1980).

\section{Determination of antimicrobial activities}

The Agar Well Diffusion method as described by Lino and Deogracious (2006) was used. By this method, $0.1 \mathrm{ml}$ of the respective standardized inoculums $(0.5 \mathrm{McF}$ arland turbidity standard $=1.0 \times 10^{8} \mathrm{cfu} / \mathrm{ml}$ ) of each test bacterium was spread into sterile Mueller Hinton Agar plates so as to achieve even growth. The plates were allowed to dry and a sterile cork borer ( $5.0 \mathrm{~mm}$ diameter) was used to bore wells aseptically in the agar plates. The extracts were prepared and serially diluted in a two-fold dilution to achieve different concentrations of $3.13,6.25,12.5,25,50,100$ and 200 $\mathrm{mg} / \mathrm{ml}$ respectively for each extract. Subsequently, $0.3 \mathrm{ml}$ of each concentration of the extracts was introduced into the wells earlier bored Agar plates. The extracts were allowed to diffuse into the medium (kept for 1 hour on the bench before incubation) at $37^{\circ} \mathrm{C}$ for 24 hours. Streptomycin was used as a positive control, while a Mueller Hinton agar plate without antimicrobials was the negative control. Antimicrobial activity of the extracts was determined by measurement of zones of inhibition produced around the wells. The diameter of the zones indicated the degree of susceptibility of the test bacteria.

\section{Determination of Minimum Inhibitory Concentration (MIC)}

The MIC of the ethanolic extracts against the test organisms was determined using the broth dilution method described by Sahm and Washington (1990). Briefly, $1.0 \mathrm{ml}$ of the extract solutions (seed, leaf and bark) at concentrations of $200 \mathrm{mg} / \mathrm{ml}, 100,50,25,12.5,6.25 \mathrm{mg} / \mathrm{ml}$ and $3.13 \mathrm{mg} / \mathrm{ml}$ were added to $9 \mathrm{ml}$ of sterile nutrient broth in different test tubes respectively. $100 \mu \mathrm{l}$ of an 18 hours culture adjusted to $0.5 \mathrm{McF}$ arland turbidity standard $\left(1.0 \times 10^{8} \mathrm{cfu} / \mathrm{ml}\right)$ was inoculated in each test tube. The tubes were incubated at 37 ${ }^{\circ} \mathrm{C}$ for 24 hours. Four control tubes were set up for each test batch of organism. These included the antibiotic control (three tubes containing the respective extracts and the growth medium without the inoculums) and a blank (a tube containing only sterile nutrient broth). The tube with the lowest concentration of the extracts (highest dilution) which had no detectable bacterial growth when compared with the control tube (using both physical and spectrophotometer observations) was considered the Minimum Inhibitory Concentration (MIC).

\section{Determination of Minimum Bactericidal Concentration $(M B C)$}

The Minimum Bactericidal Concentration of the extracts was determined by subculturing test solutions which showed no detectable growth (no turbidity after 24 hours incubation) onto fresh Nutrient Agar plates (the recovery medium) and incubated further for 24 hours. Absence of growth on the recovery medium indicated bactericidal effect, while the appearance of growth on further incubation indicated bacteriostatic effect.

\section{Phytochemical screening of ethanolic extract}

The extracts were screened for the presence of carbohydrates, tannins, alkaloids, saponins, polyphenols and other constituents successively as described by Odebiyi and Sofowora (1978) and Herbune (1973).

\section{Results and Discussion}

The current experiment investigated and compared the antimicrobial activity of the ethanolic extracts of leaf, bark and seed of $V$. paradoxa (Shea butter tree) against selected clinical bacterial isolates (Staphilococcus aureus, Klebsiella pneumoniae and Escherichia coli. $V$. paradoxa) as it has recently been a research focus as potential source for drug development due to its antibacterial (El-Mahmood et al., 2008) and anti fungal (Ahmed and Sani, 2013) activities. 
266

Table 1. Phytochemical screening of crude extracts of Vitellaria paradoxa

\begin{tabular}{|c|c|c|c|}
\hline Phyto-constituents & Bark & Seed & Leaf \\
\hline General glycosides & + & + & + \\
\hline Tannins & + & + & + \\
\hline Steroids & - & - & + \\
\hline Saponins & + & + & + \\
\hline Carbohydrates & + & + & + \\
\hline Alkaloids & + & + & + \\
\hline Polyphenols & + & + & - \\
\hline Terpenoids & + & + & + \\
\hline
\end{tabular}

Table 2. Antimicrobial activity of $V$.paradoxa extracts against Staphylococcus aureus

\begin{tabular}{ccccc}
\hline \multirow{2}{*}{ Concentration $(\mathrm{mg} / \mathrm{ml})$} & \multicolumn{3}{c}{ Diameter of inhibition zones of $V$.paradoxa extracts and commercial antibiotic $(\mathrm{mm})$} \\
\cline { 2 - 5 } & Bark & Seed & Leaf & Streptomycin \\
\hline 200 & $12.5 \pm 02$ & $14.0 \pm 03$ & $15.0 \pm 03$ & $17.0 \pm 03$ \\
100 & $10.0 \pm 01$ & $12.0 \pm 01$ & $8.0 \pm 02$ & $16.0 \pm 02$ \\
50 & $8.0 \pm 01$ & $10.5 \pm 02$ & $5.5 \pm 01$ & $15.0 \pm 03$ \\
25 & $7.5 \pm 03$ & $9.0 \pm 03$ & $5.0 \pm 03$ & $14.0 \pm 01$ \\
12.5 & $4.5 \pm 03$ & $8.0 \pm 03$ & $3.0 \pm 01$ & $12.0 \pm 00$ \\
6.25 & $3.0 \pm 01$ & $5.0 \pm 02$ & $3.0 \pm 01$ & $8.0 \pm 00$ \\
3.13 & -- & -- & -- & $3.0 \pm 02$ \\
\hline
\end{tabular}

Staphylococcus aureus McFarland turbidity standard $\left(1.0 \times 10^{8} \mathrm{cfu} / \mathrm{ml}\right)$

Table 3. Antimicrobial activity of $V$. paradoxa extracts against Escherichia coli

\begin{tabular}{ccccc}
\hline \multirow{2}{*}{ Concentration $(\mathrm{mg} / \mathrm{ml})$} & \multicolumn{3}{c}{ Diameter of inhibition zones of $V$. paradoxa extracts and commercial antibiotic $(\mathrm{mm})$} \\
\cline { 2 - 5 } & Bark & Seed & Leaf & Streptomycin \\
\hline 200 & $14.0 \pm 02$ & $14 \pm 00$ & $14.5 \pm 01$ & $17.5 \pm 00$ \\
100 & $11.5 \pm 03$ & $10.5 \pm 00$ & $13.5 \pm 01$ & $16.0 \pm 02$ \\
50 & $7.5 \pm 03$ & $7.5 \pm 02$ & $11.5 \pm 00$ & $15.0 \pm 03$ \\
25 & $6.0 \pm 03$ & $6.0 \pm 02$ & $7.0 \pm 03$ & $14.0 \pm 03$ \\
12.5 & $4.0 \pm 01$ & $5.0 \pm 02$ & $5.0 \pm 00$ & $12.0 \pm 01$ \\
6.25 & $3.0 \pm 03$ & $3.0 \pm 01$ & $4.0 \pm 02$ & $7.0 \pm 00$ \\
3.13 & - & -- & - & $3.0 \pm 01$ \\
\hline Escherichia coli McFarland turbidity standard $\left(1.0 \times 10^{8} \mathrm{cfu} / \mathrm{ml}\right)$ & & &
\end{tabular}

Escherichia coli McFarland turbidity standard $\left(1.0 \times 10^{8} \mathrm{cfu} / \mathrm{ml}\right)$

Table 4. Antimicrobial activity of $V$.paradoxa extracts against Klebsiella pneumoniae

\begin{tabular}{ccccc}
\hline \multirow{2}{*}{ Concentration $(\mathrm{mg} / \mathrm{ml})$} & \multicolumn{4}{c}{ Diameter of zones of inhibition of extracts and antibiotics $(\mathrm{mm})$} \\
\cline { 2 - 5 } & Bark & Seed & Leaf & Streptomycin \\
\hline 200 & $13.5 \pm 00$ & $12.5 \pm 03$ & $9.0 \pm 02$ & $18.0 \pm 03$ \\
100 & $9.5 \pm 03$ & $6.0 \pm 02$ & $7.0 \pm 00$ & $16.0 \pm 02$ \\
50 & $7.0 \pm 01$ & $5.0 \pm 03$ & $3.5 \pm 01$ & $15.0 \pm 03$ \\
25 & $7.0 \pm 01$ & $3.5 \pm 03$ & $2.0 \pm 02$ & $14.0 \pm 01$ \\
12.5 & $4.5 \pm 03$ & $0.5 \pm 02$ & $1.5 \pm 02$ & $12.0 \pm 00$ \\
6.25 & $3.0 \pm 01$ & - & - & $6.0 \pm 01$ \\
3.13 & - & - & - & $3.0 \pm 01$ \\
\hline Klebsiella pneumoniae McFarland turbidity standard $\left(1.0 \times 10^{8} \mathrm{cfu} / \mathrm{ml}\right)$ & & &
\end{tabular}

\section{Phytochemical composition}

Phytochemical composition of $V$. paradoxa is shown in Table 1. General glycosides, tannins, saponins, carbohydrates, alkaloids and trepenoids were present in all plant parts (stem bark, root and leaf) of $V$. paradoxa ethanolic extracts. Steroids were absent in both the stem bark and seed, while leaf extract was shown to lack polyphenols. These bioactive compounds have been demonstrated to be responsible for the antimicrobial activity of medicinal plants (Mathias et al., 2007).

Effect of ethanolic extracts of $V$. paradoxa parts against selected organisms

As shown in Tables 2, 3 and 4, all the plant parts tested, the bark, leaf and root respectively, showed antibacterial activity against the selected clinical isolates. The leaf extract showed the highest activity against all tested organisms and its efficacy was comparable to the commercial antibiotic (streptomycin) at the highest concentration $(200 \mathrm{mg} / \mathrm{ml})$ against test organisms. This higher activity is thought to be premised upon the presence of steroids, which was absent in both the bark and the seed extract. The absence of steroids in the bark of $V$. paradoxa has been reported (El-Mahmood et al., 2008). No activity was shown at the lowest concentration $(3.13 \mathrm{mg} / \mathrm{ml})$ of all extracts.

Klebsiella pneumoniae McFarland turbidity standard (1.0 x $10^{8} \mathrm{cfu} / \mathrm{ml}$ )

Antibacterial activity of the ethanolic extracts of $V$.paradoxa is organisms dependent. Each tested organism showed varying 
Table 5. Minimum Inhibitory Concentration (MIC) and Minimum Bactericidal Concentration (MBC) of S. aureus, E. coli and K. pneumonia

\begin{tabular}{ccccccc}
\hline \multirow{2}{*}{ Organisms } & \multicolumn{2}{c}{ Minimum Inhibitory Concentration $(\mathrm{MIC})$ of extracts $(\mathrm{mg} / \mathrm{ml})$} & \multicolumn{3}{c}{ Minimum Bactericidal Concentration $(\mathrm{MBC})$ of extracts $(\mathrm{mg} / \mathrm{ml})$} \\
\cline { 2 - 6 } & Bark & Seed & Leaf & Bark & Seed & Leaf \\
\hline Klebsiella pneumoniae & 6.25 & 12.5 & 12.5 & - & - & - \\
Staphylococcus aureus & 6.25 & 6.25 & 6.25 & - & - & - \\
Escherichia coli & 6.25 & 6.25 & 625 & - & - & - \\
\hline
\end{tabular}

KEY: - Not achieved

response to the respective extracts at different concentrations. Leaf and bark extracts were more potent against $E$. coli and $S$. aureus, while Klebsiella pneumoniae was more susceptible to bark extract treatment. Among the three isolates, $E$. col $i$ was the most susceptible organism to all $V$. paradoxa extracts (Tables 2, 3, 4). Klebsiella pneumoniae was the least susceptible, while Staphylococcus aureus was susceptible, but slightly less susceptible as $E$. coli. The differences in the susceptibility of the tested organisms and variations in the specific activity of each extract may be due to the physiological properties of the clinical isolates and the presence or absence of some active principles in the extracts. More so, the sensitivity of the organisms, as indicated by the diameter of the inhibition zones (Tables 2, 3, 4) was proportional to the concentration of the respective extracts. At the highest concentration $(200 \mathrm{mg} / \mathrm{ml})$, all organisms were sensitive to the $V$. paradoxa extracts. Progressive decrease in respective extract concentration leaded to a proportionate reduction of the inhibition zone around each organism. Similar reports (Adamu et al., 2013; Arekemase et al., 2013) have shown that higher concentrations of antimicrobial substances showed appreciable antimicrobial activity.

All $V$. paradoxa extracts exhibited bacteriostatic effects (Table 5) on all tested clinical isolates, but showed different minimum inhibitory concentration (MIC) which was also different with respect to each organism tested in the experiment. The bacteriostatic effect of these plant parts could possibly be due to the presence of saponins, which demonstrate remarkable physiological activity and forms lather, responsible for wound and skin protection (Ahmadu et al., 2006). Specifically, saponins have been suggested to exhibit greater antimicrobial effect and could serve as a precursor of steroidal substances with a wide range of physiological activities. The MIC of the stem bark extract was $6.25 \mathrm{mg} / \mathrm{ml}$ against all the organisms, while the seed and leaf extracts had MIC of $6.25 \mathrm{mg} / \mathrm{ml}$ against $E$. coli and $S$. aureus, but $12.5 \mathrm{mg} / \mathrm{ml}$ against $K$. pneumonia respectively. However, at 12.5 $\mathrm{mg} / \mathrm{ml}$, all $V$. paradoxa extracts showed antibacterial activity against all the clinical isolates. The variation in the MIC may be due to the phytochemical composition of the respective ethanolic extracts and the genetic make-up of each test organisms. Different organisms have been shown to respond differently to different and same concentrations of a specific medicinal plant (Philip et al., 2009).

As shown in Table 5, the plant extracts were not bactericidal on the tested organisms at all the concentrations. This was demonstrated by the re-growth of the organisms when samples taken from around the clearance zone were cultured on fresh nutrient agar plates.

\section{Conclusions}

The ethanolic extracts of the bark, seed and leaf of Vitellaria paradoxa have demonstrated antimicrobial activities against the tested clinical isolates (E. coli, S. aureus and Klebsiella pneumonia), thus justifying its use in traditional medicine for treating different diseases associated with the tested isolates, as it also could serve as a new and cheaper alternative for antibiotic sources. The clinical isolates used for this investigation are associated with various human diseases like gastrointestinal tract infections, pneumonia and body superficial wound infections. As shown in this study, $V$. paradoxa could be used as a potential source of antibiotic substance for a drug development against the diseases caused by this group of both superficial and enteric organisms. Further toxicological, purification and identification studies could be carried out to investigate the general effects of the use $V$. paradoxa for drug development.

\section{Acknowledgments}

Authors wish to thank Dr. M. O. Ameen, Department of Chemistry, Faculty of Physical Sciences, University of Ilorin, Nigeria, for his valuable assistance during the course of this research.

\section{References}

Acheampong YB, El-Mahmood MA, Olurinola PF (1988). The antibacterial properties of the liquid antiseptic TCP. Indian Journal of Pharmaceutical Sciences (3):183-186.

Adamu HM, Ushie OA, Nansel E (2013). Antimicrobial activity of oil from Butyrospermum parkii seed (Shea butter). International Journal of Modern Biology and Medicine 3(2):50-59.

Ahmadu AA, Akpulu IN, Hassan HS, Sule MI, Pateh UU (2006). Preliminary phytochemical and antimicrobial screening of the leaves of Byrsocarpus coccineus Schum \& Thonn (Connaraceae). Jounal of Pharmacy and Bioresouces 3(2):107-110.

Ahmed RN, Sani A (2013). Antimycotic activity and toxicological effects of stem bark extract of Vitellaria paradoxa in wistar rats. Sci Int (Lahore) 25(1):91-102.

Arekemase MO, Oyeyiola GP, Balogun KI (2013). Assessment of bitter leaf (Vernonia amygdalina) on some selected pathogenic organisms from University of Ilorin teaching hospital. Journal of Microbiology, Biotechnology and Food Scieces 2(5):2360-2365.

Barry AL, Thornsberry C (1980). Susceptibility testing: Diffusion test procedure. Manual of Clinical Microbiology. 3rd Edition, ASM Washington DC, USA.

Calixto JB (2000). Efficacy, safety, quality control, marketing and regulatory guidelines for herbal medicine (Phytotherapeutic agents). 
Brazilian Journal of Medical and Biological Research 33:179-189.

Dalziel JM (1968). The useful plants of West Tropical Africa. Nigeria National Press Ltd, Apapa, Lagos pp 232-233.

El-Mahmood AM, Doughari JH, Ladan N (2008). Antimicrobial screening of stem bark extract of Vitelleria paradoxa against some enteric pathogenic microorganisms. African Journal of Pharmacy and Pharmacology 2(5):089-094.

Hall JB, Aebisher DP, Tomlinson HF, Osei-Amaning E, Hindle HR (1996). Vitellaria paradoxa: A monograph. School of Agriculture and Forest Sciences Publication, University of Wales.

Herbune JR (1973). A guide to modern techniques of plant analysis. Chapman and Hall, London.

Hong TD, Linington S, Ellis RH (1996). Seed storage behaviour, a compendium. Handbook for Genebanks: No. 4 Intl Plant Genetic Resources Inst, Rome, Italy.

Lino A, Deogracious O (2006). The in-vitro antibacterial activity of Annona senegalensis, Securidaccalongi pendiculata and Steganotaenia araliacea - Ugandan Medicinal Plants. African Health Sciences 6(1):31-35.

Mann A, Abalaka ME, Garba SA (1997). The antimicrobial activity of the leaf extracts of Calotropis procera. British Journal of Biomedical Letters 55:205-210.

Mathias SN, Ilyas N, Musa KY (2007). Phytochemical constituents of some medicinal plants used amongst the Takkad people of Southern Kaduna, Nigeria. Chem Class Journal 4:70-75.
Odebiyi A, Sofowora AE (1978). Phytochemical screening of Nigerian medicinal plants. Part II. Lloydia 41(3):234-246.

Philip K, Malek SNA, Wirakarnain S, Sim KS, Saravana K, Hong SL, Lee GS, Syarifah NSA. Rahman (2009). Antimicrobial activity of some medicinal plants from Malaysia. American Journal of Applied Sciences 6(8):1613-1617.

Prescott ML, Harley PJ, Klein AD (2002). Microbiology. 7th edition. McGraw Hill Inc.

Rios JL, Recios MC (2005). Medicinal plants and antimicrobial activity. Journal of Ethno pharmacology 100:80-84.

Sahm D, Washington F (1990). Antimicrobial susceptibility test dilution method. In: Lennette EH (Ed), Manuals of Clinical Microbiology, $5^{\text {th }}$ Edition. America Society of Microbiology, Washington DC pp 1105-1116. 